Tomislav Č A N K O V I Ć (Zagreb)

tomislavcankovic@protonmail.com

\title{
ANTIČKI I MITOLOŠKI MOTIVI U ZBIRCI CARMINA BURANA
}

Primljeno: 23. 9. 2019.

UDK: 821.124.09-1

\begin{abstract}
Ovaj rad analizira funkciju i svrhu te sadržajne i formalne karakteristike antičkih i mitoloških motiva u pjesmama zbirke Carmina Burana, koja pripada počesto zanemarenom razdoblju u povijestima književnosti, a to je latinsko srednjovjekovlje. Također, ispituju se različiti odnosi između pojedinih antičkih motiva i lirskih subjekata te kako se ti motivi uklapaju u kontekst pojedine pjesme, ali i cjelokupne zbirke. Pritom su obuhvaćeni samo oni motivi koji pripadaju antičkoj grčkoj i rimskoj tradiciji, a ne uzimaju se u obzir judeo-kršćanske figure, koje prožimaju zbirku u dovoljno velikom broju da zaslužuju vlastiti rad. Usto, kako se Publija Ovidija Nazona često imenuje ključnim uzorom golijardima, ispituju se konkretni utjecaji njegovih djelâ i njegove militaristički koncipirane ljubavi na njihovo pjesništvo. Rad se pritom zadržava na pjesmama obilježenim osnovnim tematskim fascinacijama koje se golijardima najčešće pripisuju, a to su krčma, vino, kocka, ljubav uvjetovana tjelesnim ispunjenjem te satirički i antiklerikalni angažman.
\end{abstract}

Ključne riječi: golijardi, Carmina Burana, srednjovjekovna latinska poezija, mitološki motivi, Ovidije

\section{O GOLIJARDIMA I ZBIRCI CARMINA BURANA}

Premda se danas još uvijek u svakodnevnom govoru osjeti odjek prezrivog odnosa talijanskog humanizma prema srednjovjekovlju, među (književnim) povjesničarima sve više prevladava mišljenje da se unatoč tektonskim promjenama ne može govoriti o prekidu s antičkom tradicijom, već o njezinu nastavku, ili možda točnije, preobrazbi, s obzirom na sve tješnje veze sa sve dominantnijim i teologijom potkovanijim kršćanstvom. Naravno, u srednjovjekovlju opada razina pismenosti i opće erudicije, odnosno one se sužavaju na djelokrug crkvenih institucija, ali unutar njih se, u kontekstu novog vremena nove vjere, čuvala i transformirala antička tradicija, te su rimska kultura i latinski jezik nastavili biti okosnicom književnog, kultur- 
nog, znanstvenog i političkog života, barem u okvirima onoga što se naziva latinskim srednjovjekovljem (Curtius 1998: 28-39). Zahvaljujući latinskom književnost je postala europskom, svjesna svojih antičkih temelja, ali prožeta u svojim počecima duhom kršćanstva i Crkve, dok je u kasnijim godinama srednjega vijeka počela slobodnije otvarati svoje okrilje svjetovnim temama.

Na toj putanji ističu se XII. i XIII. stoljeće kao razdoblje europskog intelektualnog i ekonomskog uzleta, razvoja gradova i osnivanja obrazovnih institucija bez presedana - prvih sveučilišta. Svojevrsnu materijalizaciju te "kulminacije latinske poezije i znanosti" (Curtius 1998: 35) predstavlja zbornik Carmina Burana (odnosno Buranske pjesme), koji se obično datira oko 1230. godine (Šešelj 2000: 134). Sastoji se od 323 zasebno označene jedinice kojima dominira latinski jezik te koje su podijeljene u pet cjelina (carmina moralia et satirica, carmina amatoria, carmina potoria, ludi, supplementum). Zbornik karakterizira, osim izrazite formalne raznolikosti, i prožetost širokim spektrom tema, od nježnijih ljubavnih stihova do pjesama nabijenih izraženim erotizmom, od dirljivih religioznih lamentacija i križarskih himni do satirične i antiklerikalne poezije, od krčmarskih napjeva do moralnih i duboko intelektualnih strofa. Kao takav jasno svjedoči o vitalnosti srednjo74 vjekovne književne produkcije, ali i društva općenito.

Koegzistencija sekularne i religiozne poezije pritom ne bi trebala čuditi jer one nisu bile međusobno isključive, već su s lakoćom mogle dijeliti tekstni i izvantekstni prostor, na što ukazuju i sami golijardi, kojima se obično pripisuje autorstvo barem sekularnog dijela zbirke. Premda su ti većinom anonimni pjesnici u izvorima ostali zabilježeni kao nevaljalci koji su Crkvi zadavali ne samo poetske nego i vrlo praktične probleme, ${ }^{1}$ ipak se radi o lutajućim studentima i klericima koji su, prema tome, bili dio obrazovnih i crkvenih institucija. Međutim, budući da su ujedno i književnopovijesni fenomen, kada se govori o golijardima, ključnom treba biti njihova performativna djelatnost, odnosno poetsko stvaralaštvo okupljeno ponajviše upravo u zbirci Carmina Burana. U literaturi se može naići na različita mišljenja o tome što bi pri definiranju njihove poetike trebalo istaknuti, a što zanemariti (Carpenter 2001: 21-23), no kao okviri osnovnih poetskih konvencija pjesništva golijarda najčešće se navode satirički antiklerikalni angažman,

${ }^{1}$ Primjerice, trijerska provincijska sinoda iz 1227. godine okrivila je lutajuće studente, odnosno golijarde da ometaju misna slavlja pjevanjem nekih svojih stihova za vrijeme izvođenja himni (Waddell 1961: 286), dok se Henrik iz Suse pri elaboraciji mogućnosti njihova kažnjavanja i pomilovanja dotaknuo nekih od poznatijih golijardskih grijeha, kao što su česti posjeti krčmama i bludnicama te kockanje (Waddell 1961: 288). 
ljubav uvjetovana tjelesnim ispunjenjem te slavljenje krčmi, vina i kocke. Te karakteristike nisu isključivo vlasništvo golijardskog pjesništva niti su specifičnost latinskog srednjovjekovlja, već pripadaju novom kontekstu rastuće intelektualne i sveučilišne klime te jačanja moći i autoriteta papinstva. $\mathrm{U}$ jeku reformnog pokreta u Crkvi, s kulminacijom u pontifikatu Inocenta III. i njegovu IV. lateranskom koncilu 1215. godine, kojim se nastojao ostvariti ideal besprijekornog klera, odnosno monasticizirati kler i u praksi uspostaviti jasnu distinkciju između laičke i klerikalne sfere društva (Leyser 2010: 14-17), nastaje golijardska poezija kao "svjedočanstvo sve snažnijeg sekularnog duha" (Raby 1997: 276), koji je svoje mjesto našao i u crkvenim krugovima. Ona je reakcija na pojačan pritisak crkvenih odredbi, uperen protiv njezinih obilježja otvoreno negativno nastrojenih prema idealima redovništva i klerikalne čistoće. Golijardi su, dakle, egzistirali na razmeđu tih dviju sfera, nastojeći iskoristiti učenost i privilegije crkvenih krugova te uživanje u laičkim aktivnostima koje su se klericima sve strože zabranjivale, a kojih se oni nisu mogli odreći.

U tom su procesu golijardi imali ulogu u održavanju antičke tradicije živim elementom srednjovjekovne kulture, što nas dovodi do teme ovoga rada, okružene navedenom kontekstnom skicom, a to je analiza metode upotrebe, funkcije i svrhe antičkih motiva u pojedinim pjesmama i zbirci kao cjelini te oprimjerivanje i konkretiziranje općih mjesta golijardskog pjesništva. Pritom su uzete u obzir samo pjesme pisane latinskim jezikom (koje, srećom, čine većinu, uz otprilike pedeset pjesama na srednjovisokonjemačkom jeziku) te motivi koji pripadaju pretkršćanskoj rimskoj i grčkoj tradiciji, kako mitološkoj tako i povijesnoj. To znači da su isključeni judeo-kršćanski motivi jer oni zbog svoje brojnosti ipak zaslužuju privilegij posebnog rada. ${ }^{2}$

${ }^{2}$ Svi su prijevodi s latinskog moji, a ta je odluka proizašla iz dvaju razloga. Prije svega, prepjevi ili barem prijevodi Buranskih pjesama na hrvatski više su nego oskudni. Koliko mi je poznato, na raspolaganju su tek džepno izdanje Matice hrvatske sa sedamnaest prepjeva (Šešelj 2000) te Latinska poezija srednjeg vijeka sa samo njih deset (Grubišić 2010). S druge strane, metoda analize zahtijevala je načelo doslovnosti radi sadržajne vrijednosti, pa su se kao rješenje nametnuli nemetrički prijevodi, pri čemu sam zadržao tek grafički oblik stiha, imajući na umu vizualni dojam i lakše snalaženje.

Također, svi stihovi korišteni za potrebe ovoga rada označeni su kraticom CB i brojem pjesme kojoj pripadaju, zbog čega se lako mogu provjeriti u digitalnoj bazi Bibliotheca Augustana, odakle sam ih doslovno citirao. Ona nudi vrlo praktičnu verziju standardiziranog izdanja Buranskih pjesama koju su tridesetih godina prošlog stoljeća donijeli Alfons Hilka i Otto Schumann: Bibliotheca Augustana. Carmina Burana. http://www.hs-augsburg.de/ harsch/ Chronologia/Lspost13/CarminaBurana/bur_car0.html (zadnji pristup 16. 4. 2020). 


\section{CARMINA MORALIA ET SATIRICA}

Reputacija koju Carmina Burana danas uživaju u široj kolektivnoj svijesti počiva ponajviše na naporima koje je njemački skladatelj Carl Orff uložio sredinom tridesetih godina prošloga stoljeća u njihovo uglazbljivanje. Tekstnost ukupne kolekcije latinskih pjesama iz XII. i XIII. stoljeća zasjenjena je novim glazbenim životom udahnutim selekciji skromnoga opsega (dvadeset i četiri pjesme), ali značajnog kulturnog dosega. Orff je prvo mjesto u svojoj scenskoj kantati dao sada nepogrešivo prepoznatljivoj pjesmi O Fortuna, koja je u popularnim vizualnim medijima često auditivno sredstvo naglašavanja kakvog tragičnog, epskog ili sudbinski prekretničkog događaja, katkada i radi humorističnog efekta. Tko ne bi prepoznao kultne, gromoglasne početne stihove u izvedbi miješanoga zbora popraćenoj timpanima i činelama:
O Fortuna,
O, Fortuno,
velut luna
poput mjeseca
statu variabilis;
promjenjivog si stanja.

(CB 17, st. 1-3)

Sljedeće mjesto u kantati pripalo je pjesmi slične pouke, svojevrsnom opisu u prvom licu poznatog prikaza Kola Sreće koji krasi početak rukopisa:

Fortune plango vulnera stillantibus ocellis, quod sua michi munera subtrabit rebellis. [...]

In Fortune solio sederam elatus, prosperitatis vario flore coronatus; quicquid enim florui felix et beatus, nunc a summo corrui gloria privatus.

Fortune rota volvitur: descendo minoratus;
Oplakujem rane Fortune očima koje suze, jer mi je svoje darove uzela buntovna. [...]

Na prijestolju Fortune sjedio sam uzvišen, raznovrsnim cvijećem blagostanja okrunjen; kako god da sam, naime, cvjetao sretan i blažen, sada sam srušen s vrha lišen slave.

Okreće se Kolo Fortune: padajući sam umanjen; 
alter in altum tollitur; nimis exaltatus

rex sedet in vertice caveat ruinam!

nam sub axe legimus

Hecubam reginam.

(CB 16, st. 1-4, 9-24) drugi se uzdiže u visinu;

pretjerano uzvišen

kralj sjedi na vrhu -

neka se čuva propasti!

Naime, pod osovinom uočavamo

kraljicu Hekubu.

U Buranskim pjesmama odvija se sukob između dviju konvencija, prevrtljivosti sudbine, stalne opasnosti za lagodan život te bezbrižnosti mladenačkih dana i uživanja. On ipak nije ravnomjeran jer je prva strana brojčano nadjačana, a Fortuna, rimska božica sreće, unatoč dojmu veličine koji ostavljaju počeci kantate, zaokuplja tek devet pjesama, od kojih je najviše, njih četiri, grupirano u carmina moralia et satirica. Njezina ključna karakteristika sažeta je u ovim stihovima:

Dat Fortuna bonum, sed non durabile donum;

Attollit pronum, faciens de rege colonum.

Fortuna daruje dobar, ali ne trajan dar;

podiže pognutoga ona koja kralja čini kolonom.

(CB 18, st. 7-8)

Kako i priliči neumoljivom držaču nepredvidivih uzda nad sudbinom kakva je Fortuna, lirski su joj subjekti redovito podređeni, bespomoćno se žaleći na nestalnost njezinih darova (CB 16, st. 3-4; CB 18), njezine naklonosti i nje same. To je osnovna misao koja stoji iza likovnog prikaza Fortune u rukopisu te koja pokreće poetske elaboracije i varijacije na temu nezaustavljivosti i gluhoće njezina Kola te prolaznosti sretnih okolnosti (iako takva reprezentacija nije isključivo intelektualno vlasništvo Buranskih pjesama). Razumljivo je stoga da je radi naglašavanja jaza između vrha i dna Kola omiljenom bila metoda kontrastiranja i supostavljanja krajnosti - mali je korak od kraljevske časti do kolona znatno skromnijih privilegija, a potpora koju Fortuna pruža "pognutomu” privremena je naklonost koja će se nesumnjivo preokrenuti u propast, kako i upozorava CB 16. Lirski subjekt te pjesme čini puni krug od primatelja darova Fortune preko onoga koji sjedi na njezinu prijestolju do pada s prijestolja i vraćanja na početnu nemilost, te je nemoćan pred njezinom voljom, odnosno pasivan je, što je dodatno naglašeno upotrebom participa perfekta pasivnog (elatus, coronatus, privatus, 
minoratus). Takoder, Fortuna je u pravilu odsutna i nevidljiva sila, spoznatljiva samo preko njezinih sredstava i posljedica, a jedini pokušaji uspostave dijaloga, apostrofe u pjesmi CB 17 (O Fortuna) i CB 14, završavaju neuspjehom. U potonjoj njezinu prevrtljivost nisu izbjegla ni najslavnija imena:

\section{Edificat \\ Fortuna, diruit; \\ nunc abdicat, \\ quos prius coluit; \\ quos noluit, \\ iterum vendicat \\ bec opera \\ sibi contraria, \\ dans munera \\ nimis labilia; \\ [...]}

Quid Dario

78 regnasse profuit?

Pompeïo

quid Roma tribuit?

succubuit

uterque gladio.

eligere

media tutius

quam petere

rote sublimius

et gravius

a summo ruere:

[...]

Subsidio

Fortune labilis

cur prelio

Troia tunc nobilis,

nunc flebilis

ruit incendio?

quis sanguinis

Romani gratiam,
Gradi

Fortuna, ruši;

sad se odriče

onih za koje se prije brinula;

one koje nije htjela

opet si prisvaja

ova postupkom

suprotnim,

dajući darove

pretjerano prolazne;

[...]

Što je Dariju

koristilo to što je vladao?

Pompeju

što je Rim poklonio?

Podlegao je

maču i jedan i drugi.

Izabrati

sredinu sigurnije je

nego težiti

prema vrhu kola

i još teže

s vrhunca se srušiti:

[...]

Pomoću

Fortune prolazne

zašto je u boju

Troja, tada plemenita,

sada žalosna,

srušena ognjem?

Tko je krvi

rimske milost, 


\section{quis nominis}

Greci facundiam, quis gloriam

fregit Carthaginis? tko imena

grčkog rječitost, tko slavu

Kartage uništio?

(CB 14, st. 17-26, 33-44, 49-60)

Uputa je ikarovska - sigurnost je u sredini, a stremljenje visinama vodi tek u neizbježnu propast. Kao pomoć u učvršćivanju savjeta te u službi argumentacije i upozorenja prizvani su motivi iz antike - perzijski kralj Darije i rimski državnik Pompej kao primjeri neslavno propalih vlastodržaca te četiri naroda, Trojanci, Rimljani, Grci i Kartažani, čija se moć pokazala uzaludnom protiv volje Fortune. Završni stihovi pjesme CB 16 slične su svrhe - lirski subjekt upozorava tek ustoličenog kralja na efemernost njegova prijestolja podsjećajući na zlu kob trojanske kraljice Hekube koju prepoznaje u figuri položenoj pod osovinom Kola Sreće (uz koju stoje riječi sum sine regno u početnoj ilustraciji rukopisa). Hekuba, žena kralja Prijama, svjedočila je pogibiji svojeg brojnog potomstva i paležu Troje, izgubila kraljevsko dostojanstvo i pala u Odisejevo zarobljeništvo te konačno ostala bez vlastite ljudskosti preobrazbom u psa uslijed osvetničke srdžbe (Ovidije, Metamorfoze XIII.404-575).

S povlačenjem pretkršćanskih vjerovanja promijenio se i odnos prema Fortuni. Budući da se izravno kosila s idejom o Božjoj providnosti, kršćanska teologija nije ju mogla prihvatiti ni kao božicu ni kao objašnjenje uređenja i funkcioniranja svijeta. Za sv. Augustina rimska koncepcija Fortune puna je logičkih kontradikcija (Brumble 1998: 123; Augustin, De civitate Dei IV.18-19). Boetijeva Utjeha filozofije lišila je Fortunu božanskih sposobnosti i svela ju tek na fiktivnu alegorijsku figuru koja se u idućim stoljećima rabila (pa i u Buranskim pjesmama) kao indikator duhovnog stanja lirskog subjekta i drugih tekstnih osoba. Sreća i sudbina, posljedično i Fortuna, postale su podložnice zakonâ nepokretne i nepromjenjive providnosti kao njezine pokretne manifestacije u granicama osjetilnog svijeta (Brumble 1998: 119-120, 123-124). Pa ipak, iako je izgubila božanske atribute, Fortuna je ostala potentan simbol, posebice za nepovoljne okolnosti kada u pozadini tih kršćanskih intervencija implicira posvemašnji pesimizam lirskog subjekta i njegovu nemogućnost spoznavanja svrhovitosti iza svakog, pa i najgoreg slučaja, koji se tek pokorava zakonitostima providnosti. Takva ideja crpljena je iz Ovidija (bez kršćanskih implikacija, naravno), što je praktično demonstrirano preuzimanjem stihova iz njegovih Tužaljki: 
Passibus ambiguis Fortuna volubilis errat

Et manet in nullo certa tenaxque loco;

Sed modo leta manet, modo vultus sumit acerbos,

Et tantum constans in levitate manet.

Neodlučnim koracima promjenjiva Fortuna tumara

i nije sigurna ni čvrsta ni na jednom mjestu;

već čas je vesela, čas poprima gorko lice,

i tako stalna u nestalnosti ostaje.

(CB 18, st. 3-6; Ovid., Tris. 5.8; 15-18)

No, kako bi se i očekivalo od autora djela kakvo je Ars amatoria, Ovidijev utjecaj ponajviše dolazi do izražaja u drugoj cjelini kodeksa, carmina amatoria, čije okrilje ionako čuva više antičkih motiva od prve, u kojoj brojčanu prednost uživaju likovi iz judeo-kršćanske tradicije. Uslijed te tranzicije u antičko obilje bilo bi šteta propustiti pretposljednju pjesmu prve cjeline, odnos čijeg sadržaja i položaja u zbirci proizvodi predivnu ironiju:

Omne genus demoniorum cecorum, claudorum sive confusorum, attendite iussum meorum et vocationem verborum. [...]

Per nomen mirabile atque ineffabile

Dei tetragrammaton, ut expaveatis et perhorreatis, vos exorcizo, Larve, Fauni, Manes, Nymphe,
Čitavi rode demonâ slijepih, hromih ili rasutih, obrati pozornost na zapovijed i poziv mojih riječi.

[...]

Po divnom imenu i neizrecivom Boga četveroslovnom, ${ }^{3}$ da se prepadnete i da zadrhtite, vas istjerujem, larve, fauni, mani, nimfe,

\footnotetext{
${ }^{3}$ Hebrejski YHWH, starozavjetno ime Boga.
} 


Sirene,
Adryades,
Satyri,
Incubi,
Penates,
ut cito abeatis,
chaos incolatis,
ne vas corrumptis
christianitatis.

Tu nos, Deus, conservare ab hostibus digneris!

(CB 54, st. 1-6, 47-66) ${ }^{4}$ sirene, adrijade, satiri, inkubi, penati, da smjesta odete, kaos nastanite, i da ne kvarite tkivo kršćanstva.
Ti se, Bože, udostoji izbaviti nas od neprijatelja!

\section{CARMINA AMATORIA}

Izuzme li se posljednja pjesma prve cjeline, pod brojem 55, koju tvori tek jedan distih, tim neuspjelim egzorcizmom bića antičkog podrijetla, okupljenih u kršćanskom duhu pod imenom $d(a)$ emoni, završavaju carmina moralia et satirica te nastupaju ljubavne pjesme, uvjetno nazvane tako s obzirom na druge teme skrivene među njima. One sasvim prikladno počinju stihovima:
Ianus annum circinat, ver estatem nuntiat
[...] Janus zaokružuje godinu,
proljeće najavljuje ljeto
[...]

(CB 56, st. 1-2)

${ }^{4}$ Neke jedinke ovog kataloga "demonâ" zaslužuju posebnu pozornost. Faune, nimfe, sirene i satire ne treba posebno predstavljati, kao ni mane i penate, duhove predaka, odnosno zaštitnike obitelji i ognjišta. Larve su pak zla verzija lemura, duhova svih umrlih. S inkubima se, međutim, napušta teren rimske mitologije i zalazi u patristiku - primjerice, sv. Augustin u svome djelu De civitate Dei, u kontekstu teološke rasprave o mogućnostima anđela i demona da tjelesno opće s ljudima, svjedoči o raširenoj glasini da su inkubi zlodusi koji su uspješni u pohotnim odnosima sa ženama (Augustin, De civitate Dei XV.23.1).

O adrijadama kao takvima ne nalazim ništa, no kako im ime nedvojbeno podsjeća na neku vrstu nimfa, vjerojatno se radi o alternativnom obliku za drijade ili hamadrijade, šumske nimfe. Zašto su pak one u ovim stihovima izdvojene i istaknute uz svoj hiperonim, zasad ostaje misterij. 
To je jedini primjer u kojem se javlja Janus, bog početaka, i znakovito zauzima prvo mjesto prvog stiha prve pjesme ljubavne cjeline. No, svrha mu je i vrlo praktična - osim što s drugom riječi tvori asonancu (ianus annum), dvosložnost mu se uklapa u trohejsku metričku strukturu, te kao takav zaobilazi neprikladnost mjeseca umjesto kojeg stoji, a to je ianuarius. Takoder, u tim se stihovima nazire topos frekventan u spomenutoj cjelini, inače raširen u ljubavnoj poeziji. Riječ je, naravno, o proljeću, njegovu dolasku ili već naponu snage, iako je ta konvencija poznatija kao nezaobilazno mjesto trubadurskog pjesništva. Ona trubadure uvodi u za njih karakterističan koncept udvorne ljubavi, obilježene ravnotežom ili mjerom, branom protiv razuzdanosti erosa, koja implicira koegzistenciju dviju krajnosti, radosti i patnje, pri čemu potonja označava ljubavno ispunjenje, ali ono koje ne ovisi nužno o tjelesnome (Mrkonjić i Tomasović 2012: 14). S druge strane, golijardima je proljeće uvertira upravo u erotsku ljubav, u kojoj kurzivni pojmovi prethodne rečenice nose drugo značenje. Kako golijardima nije u interesu držati eros na uzdama, tako nema potrebe za nekakvom mjerom koja bi sprječavala putene manifestacije ljubavi, što je i cilj koji prevladava u njihovu poetskom diskursu. Radost, koju je u njihovu slučaju točnije ime-

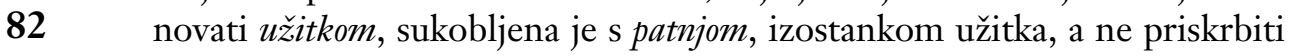
si radost/užitak (lat. gaudium), domenu Venere, znači zakazati u Ovidijevim vještinama. Dok se na tog Rimljanina u ranijim stoljećima nije pozivalo zbog njegove reputacije opscenog i nemoralnog pjesnika, XI. i XII. stoljeće osvanuli su kao aetas ovidiana (Grubišić 2012: 19), ${ }^{5}$ a golijardi su ga posebice prigrlili kao učitelja ljubavnog umijeće i mitologije (Raby 1997: 276), služeći se stečenim znanjem za vlastite poetske potrebe, što se već nazire u nastavku pjesme pod brojem 56:

Dum alumnus Palladis
Cytheree scolam
introissem, inter multas
bene cultas
vidi unam solam
facie
Tyndaridi
ac Veneri

Dok sam kao pitomac Palade u školu Kiteranke ulazio, među mnogim dobro dotjeranim vidio sam samo jednu licem Tindaridi i Veneri

${ }^{5}$ Naravno, u spomenutim stoljećima i dalje je bilo autora neprijateljski nastrojenih prema Ovidiju, koji su nastojali minimalizirati utjecaj njegovih djela o ljubavi. O Ovidijevu autoritetu u srednjem vijeku vidi: Dimmick 2003: 263-287. 
secundam, plenam elegantie et magis pudibundam.

\section{[...]}

Parce, puer, puero!

fave, Venus, tenero, ignem movens, ignem fovens, ne mori sit, quod vixero, nec sit ut Daphnes Phebo, cui me ipsum dedo! olim tiro Palladis nunc tuo iuri cedo.

(CB 56, st. 18-28, 49-57) najbližu, punu elegancije i vrlo sramežljivu.

\section{$[\ldots]$}

Čuvaj, dječače, dječaka!

Pomozi, Venero, mladomu, ti koja potičeš vatru, koja raspaljuješ vatru, da ne umrem, jer ću živjeti, i da ne bude kao Dafna Febu ona kojoj samog sebe dajem! Nekoć iskušenik Palade, sad se tvojem pravu predajem.

Nimfa Dafna, u kojoj je kršćanstvo prepoznalo tipski prikaz Djevice Marije te model uzornog i nepokolebljivo čednog kršćanina koji odolijeva napastima požude (Brumble 1998: 95), izmolila je od svog oca, riječnog boga Peneja, promjenu svoga obličja radi spasa od Apolonovih nasrtaja, te je stoga bila preobražena u lovorovo stablo (Ovidije, Metamorfoze I.452-567), a posljedično i u arhetip odbijene ljubavi. Premda je Dafna i prije nemilog susreta cijenila vlastito djevičanstvo, ne mareći za razne prosce i vjenčanje, ni ona ni Apolon ne snose posve odgovornost za svoje postupke. Krivica je na Kupidovoj demonstraciji moći, koji se osvetio Apolonu za ruganje zarazivši ga mahnitom zaljubljenošću, a spomenutu nimfu suprotnim efektom. Iz tog razloga lirski subjekt, osim neizostavnoj Veneri, svoj vapaj upućuje "dječaku" (Kupidu) moleći da njegovu izabranicu ne opsjedne isto ludilo kao Dafnu. Također, kao što Apolon nije bio vođen razumom, već nametnutim mu životinjskim instinktom (Ovidije ga uspoređuje sa psom koji lovi zeca), tako i u ljubavi prožetoj erotizmom i ganjanjem užitka ne može biti razuma. Obuzdati užitke na koje potiče Venera (Kiteranka, po otoku Kiteri) znači svrstati se uz Minervu/Paladu (Brumble 1998: 221). Slična dilema naći će se i na drugom mjestu:

Sicut in arbore

frons tremula, navicula
Kao na drvetu

list koji drhti, brodica 
levis in equore, dum caret ancore subsidio, contrario

flatu concussa fluitat:

sic agitat,

sic turbine sollicitat

me dubio

binc Amor, inde Ratio. lagana na pučini, dok je bez pomoći sidra, suprotnim vjetrom uzdrmana luta: tako muči, tako olujom uznemiruje mene neodlučnom ovdje Amor, ondje Razum.

(CB 108, st. 25-36)

Lirski subjekti obično jasno daju do znanja kojoj se strani priklanjaju, iako milost Amora i Venere nije uvijek svima dostupna:

$\begin{array}{ll}\begin{array}{l}\text { Delium flagrantem, } \\ \text { procantem, }\end{array} & \text { Delskog Apolona koji je plamtio, } \\ \text { anbelantem } & \text { mamio, } \\ \text { Daphne respuit, } & \text { čeznuo, } \\ \text { rennuit, } & \text { Dafna je odbila, } \\ \text { puduit } & \text { prezrela, } \\ \text { amplexari. } & \text { sramila se } \\ \text { michi refragari } & \text { prigrliti ga. } \\ \text { nititur, } & \text { Meni se oduprijeti } \\ \text { que petitur; } & \text { nastoji } \\ \text { subvertitur } & \text { ona koja je prošena; } \\ \text { spes mea, } & \text { uništena je } \\ \text { quia Cytherea, } & \text { nada moja, } \\ \text { lese pacis rea, } & \text { jer se Kiteranka, } \\ \text { cedit in contrarium. } & \text { kriva zbog povrijeđenog mira, }\end{array}$

(CB 109, st. 13-27)

U CB 56 Venera također služi, skupa s Helenom (Tindaridom, prema očuhu joj Tindareju, spartanskom kralju), kao osnova za usporedbu, ali budući da se lirski subjekt ne želi zamjeriti božici čiju pomoć moli, dovoljno je oprezan da svoju voljenu zadrži laskavo u njezinoj sjeni, služeći se formulacijom Veneri secundam. Venera i Helena inače su lako razumljivi dijelovi pjesničkog arsenala kao signali i mjerila ljepote:

Visus tuus splendidus erat et amenus, 
tamquam aer lucidus nitens et serenus; unde dixi sepius: "Deus, Deus meus! estne illa Helena vel est dea Venus?"

Pogled tvoj sjajan bijaše i ugodan, kao bistar sijajući zrak i vedar; stoga često rekoh: "Bože, Bože moj! Je li ona Helena ili je božica Venera?" (CB 77, st. 53-56)

Kako bi dodatno naglasio ljepotu svoje djeve, drugi je pjesnik pak posegnuo za figurom zloglasno požudnog Jupitera i primjerima njegove nevjere:

O si forte Iupiter
banc videat,
timeo, ne pariter
incaleat
et ad fraudes redeat:
si vel Danes pluens aurum
imbre dulci mulceat,
vel Europes intret taurum,
vel Ledeo candeat
rursus in olore.

(CB 83, st. 97-106)

\author{
$\mathrm{O}$, kad bi slučajno Jupiter \\ ovu vidio, \\ bojim se da bi se jednako \\ uspalio \\ i na varke vratio: \\ bilo da bi pljušteći kao Danajino zlato \\ slatkom kišom milovao, \\ ili bi se uvukao u Europina bika, \\ ili bi se ponovno zabijelio \\ u Ledinu labudu.
}

U zborniku Carmina Burana daleko je najučestaliji mitološki motiv upravo Venera. Osim tom glasovitom rimskom inačicom njezina imena pjesnici Buranskib pjesama su se, ugledajući se na Ovidijevu nomenklaturu, referirali na Veneru i drugim imenima, u prvom redu zbog praktičnih potreba metrike i/ili rime. Pjesma 56 već je otkrila jednu mogućnost (Kiteranka), no Venera se krije i u Cipranki, nazvanoj tako prema otoku Cipru uz koji ju je rodila morska pjena (prema Heziodovoj verziji), te u Dioni, premda se zapravo radi o božici kiše koju je Homer držao njezinom majkom. Ovidije u više navrata Veneru naziva Dionom; primjerice kada spominje zamke koje je postavio Vulkan, njezin muž, kako bi uhvatio nju i Marsa u preljubu (Ovidije, Ars amatoria II.573-594) te na početku treće knjige, posvećene djevojkama, udružujući ju s "dječakom koji leti svijetom", uz nadu da će biti nakloni ljubavnicima (Ovidije, Ars amatoria III.3-4). U zbirci Carmina 
Burana Diona najčešće i označava Veneru (između ostalih u CB 56, 58, 92 i 108), no gdjekad ih pjesnici razlikuju - moleći u ime kolektivnog glasa, lirski subjekt ovdje nastoji ublažiti Venerino ratničko raspoloženje i pobuditi u njoj majčinsku brigu i osjećaje pozivajući se na ime njezine roditeljice:

Parce dato pia, Cypris, agone, Okani se dane agonije, blažena Cipranko, et quia vincimur, arma repone, i jer smo pobijeđeni, odloži oružje, et quibus es Venus, esto Dione! i kojima si Venera, budi Diona!

(CB 73, st. 51-53)

Venera predstavlja sve ono zemaljsko i tjelesno u ljubavi, a uslijed različitih stupnjeva uspjeha u tome prema njoj su bili uspostavljeni različiti poetski odnosi. Za početak, u slučaju da im je ispunjenje ljubavi izvan dosega, lirski subjekti upućuju joj svoje molitve kako bi osigurali njezinu naklonost, kad im ju već izabranice uskraćuju:

Prata iam rident omnia, Sad se osmjehuju sve livade, est dulce flores carpere; te je slatko brati cvijeće; sed nox donat his somnia, ali noć daruje snove onima qui semper vellent ludere. koji bi se stalno htjeli igrati. ve, ve, miser quid faciam? Jao, jao, što da jadan radim? Venus, michi subvenias! tuam iam colo gratiam. Venero, pomozi mi! Tvoju milost sada štujem.

(CB 114, st. 7-12)

Ili u ovim stihovima koji Veneru jasno tituliraju:

Venus, amoris dea, me tibi subicio, auxilio egens tuo; iam caleo et pereo in ea!

Collaudate meam, pudicam, delectabilem, amabilem! amo ferventer eam. per quam mestus vigeo
Venero, božice ljubavi, sebe tebi podlažem, pomoć trebajući tvoju; već gorim i nestajem u ovoj!

Hvalite moju čednu, ugodnu, ljupku! Volim ju žestoko. Zbog nje žalostan živim 
et gaudeo,

illam pre cunctis diligo

et veneror ut deam. i radujem se, nju prije svih štujem i častim kao božicu.

(CB 168, st. 18-28)

Evo primjera nesebične molitve, koja uzima i druge u obzir:

Venus assit omnibus

ad eam clamantibus, assit cum Cupidine!

\section{$[\ldots]$}

Venus, que est et erat, tela sua proferat in amantes puellas!

Que amantes munerat, iuvenes non conterat nec pulchras domicellas! (CB 148, st. 7-9, 13-18)
Venera neka pomogne svima koji ju dozivaju, neka pomogne s Kupidom!<smiles></smiles>

Venera, koja jest i koja bješe, strijele svoje neka izvadi za zaljubljene djevojke!

Ona koja dariva one koji vole, mladiće neka ne smrvi ni lijepe djevojke!

S druge strane, Venera je mogla svoju milost iskazati tek polovično, potičući ljubav, nerijetko izraženu vatrenim epitetima, samo u lirskom subjektu, kojem tada na raspolaganju ostaje jedino bespomoćno žaljenje:
Veneris vincula
Okove Venere
vinctus sustineo. svezan podnosim.
pereant iacula, Neka nestanu strijele, quibus sic pereo! od kojih tako ginem! fixus sum aureo, Proboden sam zlatnom, figitur plumbeo ubodena je olovnom florens virguncula, [...] cvatuća djevojka,
(CB 106, st. 1-7)

Lamentirajući nad svojom sudbinom, lirski subjekt zahtijeva oslobođenje od nesretne i neuzvraćene ljubavi, implicirajući pritom mit o Apolonu i 
Dafni - zlatna strijela koju spominje jednaka je onoj kojom je Kupid pogodio rečenoga boga, dok je nimfu zapala olovna, koja ju je natjerala u bijeg od ljubavi. O nesretnom unutarnjem stanju izravnije svjedoče idući stihovi:

\section{Urit Venus}

corde tenus,

quam nec Rhenus

nec Euphrates maximus

valet estinguere.

me sola solvere

potest vel perdere.

\section{$[\cdots]$}

Virgo, par Tyndaridi, tuo fave Paridi! rosa prati floridi, nil repugnes Cypridi!

88

\author{
Pali Venera \\ sve do srca, \\ nju ni Rajna \\ ni Eufrat veliki \\ ne mogu ugasiti. \\ Samo me ona osloboditi \\ može ili uništiti.
}

$[\ldots]$

Djevo ravna Tindaridi, budi naklona svom Parisu!

Ružo cvjetne livade, ne opiri se Cipranki!

\section{$[\ldots]$}

Snaga ljubavi

iznutra $\mathrm{i}$ izvana

uznemiruje me

bičevima svoga bijesa.

O, Venero zlatna!

Okrutna si božica;

naime, plamenom zubljom

pržiš me.

Pa zašto bjesniš?

Zašto si me čvrstim

ranila strijelama?

Oganj me mrvi;

smrt mi je bolja

nego dug život!

quam vita longior!

(CB 103, st. 8-14, 33-36, 107-120)

Vatru ljubavi koju je božanstvo potaklo može isključivo božanstvo ugasiti, dakle sve zemaljsko je kad se radi o tome medicinski bezvrijedno, pa čak 
i goleme količine voda Rajne i Eufrata. Kako i ne bi kada je dotična djeva, ponovno, ravna glasovitoj Heleni (Tindaridi), zbog čega lirski subjekt samog sebe izjednačava s trojanskim princem. No, dok je antički Paris izabrao Veneru kao najljepšu božicu i zauzvrat dobio ljubav najljepše žene svoga doba, samozvani Paris XII. stoljeća tek je žrtva "okrutne božice" - samo u njemu plamti ljubav, dok se njegova Helena ljubavi uspješno opire. Katkada je ta ljubav toliko jaka da njezinim uzrokom nije samo Venera:

Venus me telo vulneravit aureo, quod cor penetravit, Cupido faces instillavit, Amor amorem inspiravit iuvencule, pro qua volo mori.

(CB 78, st. 15-19)
Venera me strijelom ranila zlatnom, koja je probila srce; Kupid je upalio zublje, Amor je ljubav potaknuo prema djevojci, za koju želim umrijeti.

U sljedećem primjeru otpor koji izabranica pruža zahtijeva molitvu upućenu na nekoliko božanskih adresa - izbor je u najmanju ruku neobičan, ali jasno svjedoči o njezinoj tvrdoglavosti koju lirski subjekt može savladati isključivo pomoću kolektivnog napora nebesnika:

Sitio, quod igniferos

dolores fero. Sedule

si non exoro superos:

Altitonum cum Hercule

et Iunonem cum Pallade

et Helenam cum Venere, non prospere

banc me continget vincere.
Žeđam, jer vatrene

bolove podnosim. Ustrajno

ako ne izmolim nebesnike,

Gromovnika s Herkulom

i Junonu s Paladom

i Helenu s Venerom, neće uspješno

doći do toga da ju pobijedim.

(CB 155, st. 17-24)

Upotreba realnog hipotetičkog perioda, odnosno indikativa u pogodbenoj rečenici implicira ostvarivost ili radije pretpostavku ostvarivosti metode o kojoj lirski subjekt kontemplira. Svoje nade polaže u božansku pomoć, premda je upitno koliko bogovi mogu pomoći s obzirom na to da su i sami nemoćni pred moćima ljubavi - izuzev već spomenute Apolonove nesreće CB 88 podsjeća na druga božanstva posrnula pred strijelama ljubavi:

Amor habet superos: Iovem amat Iuno;
Amor vlada nebesnicima: Jupitera voli Junona; 
motus premens efferos imperat Neptuno; Pluto tenens inferos mitis est boc uno. (CB 88, st. 1-6) gnječeći divlje osjećaje upravlja Neptunom; Pluton koji posjeduje podzemlje pripitomljen je ovim jednim.

S treće strane, sretnicima koji su svoje ispunjenje ostvarili jadikovke nisu bile potrebne, stoga su svoje pjesme mogli posvetiti zahvalama na već darovanoj pomoći:

$\begin{array}{ll}\text { Grates ago Veneri, } & \text { Zahvaljujem Veneri, } \\ \text { que prosperi } & \text { koja mi je božanskom moći } \\ \text { michi risus numine } & \text { trofej naklonjenog osmijeha } \\ \text { de virgine } & \text { od djeve } \\ \text { mea gratum } & \text { moje drag } \\ \text { et optatum } & \text { i žuđen } \\ \text { contulit tropheum. } & \text { dodijelila. }\end{array}$

$\begin{array}{ll}\text { Dudum militaveram, } & \text { Prije sam ratovao } \\ \text { nec poteram } & \text { i nisam mogao } \\ \text { boc frui stipendio; } & \text { uživati u toj plaći; } \\ \text { nunc sentio } & \text { sada osjećam } \\ \text { me beari, } & \text { da sam usrećen, } \\ \text { serenari } & \text { da se razvedrava } \\ \text { vultum Dioneum. } & \text { Dionino lice. }\end{array}$

(CB 72, st. 1-14)

Ili su pak konjunktivima nezavisnih rečenica oduševljeno pozivali na službu Veneri:

Militemus Veneri, nos qui sumus teneri!

(CB 94, st. 7-8)

Ili:

Nemus revirescit, frondet frutices, Gaj je pozelenio, listaju grmovi, biems seva cessit; leti, iuvenes,
Ratujmo za Veneru, mi koji smo mladi! otišla je okrutna zima; veseli, mladi, 
congaudete floribus!

amor allicit vos iam virginibus.

Ergo militemus simul Veneri

tristia vitemus nosque teneri!

visus et colloquio, ${ }^{6}$

spes amorque trabant

nos ad gaudia! radujte se cvijeću!

Ljubav vas sada mami djevama.

Stoga ratujmo skupa za Veneru, i klonimo se žalosti mi mladi!

Pogledi i razgovori, nada i ljubav privlače nas radostima!

(CB 144, st. 5-12)

Naravno, tu je nezaobilazno proljeće kao prethodnica ljubavnoga slavlja, radi uspostave paralelizma između izvanjskog cvjetanja prirode i unutarnjega cvjetanja ljubavi, koji opravdava ljubavne igre i posljedično potiče na uživanje u njima. No, kako demonstriraju CB 56 i CB 114, proljetni ambijent mogao je imati suprotan efekt - produbljivanje i naglašavanje žalosti lirskog subjekta koji ne može svoju probuđenu nutrinu manifestirati putenom ljubavlju upravo kada buđenje prirode pred njega postavlja takva očekivanja. Idući stihovi ipak su bliži prethodnoj pjesmi:

Estas nunc tenella vestit

fronde nuditatem arborum.

puellaris turba gestit

florem contemplari nemorum.

banc sequatur cum gaudio

iam iuvenum militia, dulcis

et leta contio!

Ergo leti aspirantes

dulcem rerum ad temperiem

iocundemur, gratulantes

Veneream ad blanditiem

et aurea Cupidinis

ad iacula! sit animus velox
Ljeto sada nježnim odijeva

lišćem golotinju drveća.

Djevojačko mnoštvo čezne promatrati cvijet gajeva.

Njega neka s radošću slijedi sada vojska mladića, sladak i veseo skup!

Stoga mi veseli, koji težimo za slatkom toplinom stvari, radujmo se, veseleći se Venerinoj dražesti i zlatnim Kupidovim strijelama! Neka je duša hitra

${ }^{6}$ Ova riječ u bazi Bibliotheca Augustana dolazi upravo u obliku colloquio, koji inače sugerira dativ ili ablativ jednine imenice koju rječnici jednoglasno nude pod colloquium, ali prema smislu rečenice to može biti jedino i isključivo nominativ. Pretpostavljam, dakle, da je riječ o grešci nepoznatog krivca te da zaista treba stajati nominativ, ali množine, odnosno colloquia, što se uklapa gramatički te u parnu shemu rimovanja. 
ad cultum virginis! $\quad \mathrm{k}$ štovanju djeve!

(CB 150, st. 7-18)

Što se tiče promjena godišnjih doba koje pozivaju na ljubavne radosti, na njih nisu imuni ni bogovi:
Estivali gaudio
tellus renovatur, militandi studio
Venus excitatur.
(CB 80, st. 1-4)

Ljetnom radošću zemlja se obnavlja, zbog žudnje za ratovanjem Venera se uzdiže!

Poput Fortune Venera je redovito nadređena lirskim subjektima - ona je metaforička božanska sila kojoj posvećuju svoje molbe ili službe te koja kao pjesnički motiv utjelovljuje karnalne im želje, bilo ostvarene bilo neostvarene, odnosno bludne manifestacije ljubavi koje su njezina domena:

Est Amor alatus puer et levis, est pharetratus.

[...]

Mittit pentagonas nervo stridente sagittas,

Quod sunt quinque modi, quibus associamur amori:

Visus; colloquium; tactus; compar labiorum

Nectaris alterni permixtio, commoda fini;

In lecto quintum tacite Venus exprimit actum.

Amor je krilat i lijep dječak s tobolcem.

[...]

Ispaljuje peterokutne strijele tetivom koja zuji, jer je pet načina kojima se združujemo u ljubavi:

pogled; razgovor; dodir; jednako miješanje uzajamnog nektara usana, prikladnoga kraja; peto, u krevetu tiho Venera predstavlja čin.

(CB 154, st. 1, 6-10)

Prethodnih šest pjesama dijele motive koji pripadaju vojničkom i ratničkom vokabularu (militare, militia, iaculum, sagitta, skupa s telum u CB 78 i 148). Budući da potječu iz Ovidijevih militaristički koncipiranih djela o ljubavi, dodatno su svjedočanstvo o njegovu utjecaju na golijarde. Ovidije 
kaže da svaki ljubavnik ratuje ("militat omnis amans" - Ovidije, Amores I.9.1) te da je ljubav vrsta ratovanja ("militiae species est amor" - Ovidije, Ars amatoria II.233), stoga njegovi učenici vlastiti diskurs prilagođuju prikladnoj terminologiji te sami sebe nazivaju vojnicima:

Iam dudum Amoris militem devotum me exhibui, cuius nutu me precipitem stulto commisi ausui, amans in periculo unam, que numquam me pio respexit oculo.

(CB 166, st. 1-6)
Već sam odavno predstavio sebe kao zavjetovanog Amorova vojnika, čijim sam nalogom sebe naglog s nepromišljenom predao smjelošću, voleći u pogibelji jednu, koja se nikada nije na mene blaženim osvrnula okom.

Na Ovidija se, dakle, golijardska tradicija oslonila i kada je riječ o Veneri, koju je prihvatila kao jednostavan, prepoznatljiv simbol požude i putene ljubavi. Naravno, ovdje za matematiku nema mjesta, stoga bi bilo nepromišljeno staviti znak jednakosti između Venere i požude, zbog primjera poput CB 77 u kojem je Venera tek osnova za usporedbu, ali je ta formula primjenjiva na većinu Buranskih pjesama u kojima se spomenuta božica javlja. U Ars amatoria Ovidije preporučuje "Venerine radosti" za utjehu uplakanoj ženi ("Veneris da gaudia flenti" - Ovidije, Ars amatoria II.459), te ga upravo Venera (odnosna Diona) potiče da nastavi svoje djelo, premda je ono što slijedi "stidno", misleći oba puta na seksualni čin (“"praecipue nostrum est, quod pudet' inquit 'opus'” - Ovidije, Ars amatoria III.770). A kako Ovidije staračku ljubav uspoređuje sa starim vojnikom ("turpe senex miles, turpe senilis amor" - Ovidije, Amores I.9.4), tako i Buranske pjesme vehementnim uzvicima navedenu ljubav rezerviraju samo za mlade:

Amor querit iuvenes, ut ludant cum virginibus;

Venus despicit senes, qui impleti sunt doloribus.

Amor traži od mladića da se igraju s djevama;

Venera prezire starce, koji su ispunjeni bolovima.

(CB 152, st. 13-14)

Iako je srednjovjekovna tradicija na tragu antičkih pisaca, posebice Platona, razlikovala dvije Venere, nebesku i zemaljsku, a na taj način uzvišenu 
i plemenitu ljubav te onu karnalnu - premda se nisu mogli dogovoriti koju predstavlja Dionina i Jupiterova Venera, a koju ona rođena iz morske pjene (Brumble 1998: 338-342) - Carmina Burana u većini se slučajeva, dakle, bave potonjom božicom. U prilog požudnoj interpretaciji služi fascinacija još od antike poslovično požudnim Parisom (Brumble 1998: 259) i njegovim izborom Venere za najljepšu božicu nauštrb Junone i Minerve, kasnije alegorijski protumačenim kao odbacivanje mudrog i dostojanstvenog života u korist pohotnoga (Brumble 1998: 258-260). Parisa se obično ne spominje bez Venere, a lirskim subjektima nerijetko služi kao identifikacijska figura, čak i u kolektivno ime:

Simus iussu Cypridis

gloriantes

et letantes

pares esse Paridis!

(CB 143, st. 27-30)
Budimo po zapovijedi Cipranke ponosni

i radosni

što smo jednaki Parisu!

Identifikacija funkcionira i u slučaju neuspješnosti u ljubavi, kada je lirski subjekt u nemogućnosti da poput drugih "Venerinih učenika" otpjeva svoja postignuća:

$\begin{array}{ll}\begin{array}{l}\text { Si de more } \\ \text { cum honore }\end{array} & \text { Kad bih po običaju } \\ \text { lete viverem } & \text { s čašću } \\ \text { nec meroris } & \text { sretno živio, } \\ \text { nec doloris } & \text { ne bih ni žalosti } \\ \text { librum legerem, } & \text { ni boli } \\ \text { salutarem gramina, } & \text { knjigu čitao, } \\ \text { me novarem, } & \text { pozdravljao bih livade, } \\ \text { mundo darem } & \text { sebe bih obnovio, } \\ \text { nova carmina. } & \text { svijetu bih dao } \\ & \text { nove pjesme. } \\ \text { Tamen cano, } & \\ \text { sed de vano } & \text { Ipak pjevam, } \\ \text { statu Veneris, } & \text { ali uzalud } \\ \text { cuius Paris } & \text { zbog stanja Venere, } \\ \text { et scolaris } & \text { čiji sam Paris } \\ \text { sum cum ceteris } & \text { i učenik } \\ \text { qui noverunt varia } & \text { s ostalima } \\ \text { koji su znali drugačije }\end{array}$


$\begin{array}{ll}\text { decantare, } & \text { pjevati, } \\ \text { veri dare } & \text { proljeću dati } \\ \text { sua gaudia. } & \text { svoje radosti. }\end{array}$

(CB 147, st. 1-20)

Premda zemaljska, Venera je i dalje redovito nadređena poetska sila te nerijetko odsutna i nezainteresirana sugovornica, neovisno o naravi obraćanja. Međutim, jedna je od Buranskih pjesama poema pisana golijardskim stihom koja praktično demonstrira iznimku od gluhe Venere, tematizirajući rijetko plodonosan susret i dijalog lirskog subjekta s božicom:

Dum caupona verterem vino debachatus, secus templum Veneris eram bospitatus. solus ibam, prospere vestibus ornatus, plenum ferens loculum ad sinistrum latus.

\section{[...]}

intus erat sonitus dulcis cantilene;

estimabam, plurime quod essent Sirene.

Kad sam od krčme krenuo, mahnit od vina, kraj hrama Venerina sam odsjeo.

Sâm sam išao, prikladno i lijepo odjeven, punu noseći torbu na lijevom boku.

$[\ldots]$

Unutra bijaše zvuk slatke pjesme;

smatrao sam da su to mnogobrojne sirene.

Pijanog pripovjedača koji želi ući u Venerin hram zaustavlja čuvarica ulaznih vrata, tražeći razlog njegova dolaska, na što on odgovara:

[...]

dixi: "necessario venio detentus.

Intus et exterius asto vulneratus a sagitta Veneris; ex quo fui natus, telum fero pectore nondum medicatus. cursu veni tacito, quo sim liberatus. 
Incessanter rogo te, virgo tu beata, ut hec verba Veneri nunties legata." [...]

\section{$[\ldots]$} rekoh: "dolazim nuždom zaustavljen.

Iznutra i izvana stojim ranjen Venerinom strijelom; otkako sam rođen, oružje nosim u grudima još neizliječen. Trkom sam došao nečujnim kako bih bio oslobođen.

Bez prestanka te molim, djevo ti blažena, da ove poslane riječi Veneri javiš." $[\ldots]$

Čuvarica, dirnuta tim riječima, odlazi k Veneri koja ga zatim prima:

Iussu sacre Veneris ductus in conclavi, cernens eius speciem fortiter expavi. flexis tandem genibus ipsam salutavi, "salve," dicens, "inclita Venus, quam optavi!"

"Quis es," inquit, "iuvenis, qui tam bene faris? quid venisti, dicito! quomodo vocaris? es tu forte iuvenis ille dictus Paris? ista de quo retulit, cur sic infirmaris?"

"Venus clementissima, felix creatura, cerno, quod preterita noscis et futura. ipse sum miserrimus, res iam peritura, quem sanare poteris tua levi cura."

"Bene," inquit, "veneris, noster o delicte iuvenis! Aptissime sodes nostre secte. si tu das denarios monete electe, dabitur consilium salutis perfecte."

"Ecce," dixi, "loculus extat nummis plenus. totum quippe tribuam tibi, sacra Venus. 
si tu das consilium, ut sat sim serenus, tuum in perpetuum venerabor genus."

Po zapovijedi svete Venere uveden sam u prostoriju; vidjevši njezinu priliku, jako sam se uplašio.

Svinutih sam ju pak koljena pozdravio, "zdravo”, govoreći, "slavna Venero, koju sam tražio!”

"Tko si", reče, "mladiću, koji tako dobro zboriš?

Zašto si došao, kaži! Kako se zoveš?

Jesi li ti možda onaj mladić zvani Paris?

Zašto tako boluješ, o čemu me ona [čuvarica] izvijestila?"

"Venero premilostiva, sretni stvore, vidim da prošlost poznaješ i budućnost. Ja sam vrlo nesretan, stvar sam koja će sada nestati, mene ćeš moći izliječiti svojom nježnom brigom.”

"Dobro si”, reče, “došao, o, naš ljubljeni mladiću, sasvim prikladno ako hoćeš k našoj družbi.

Ako daš denare iz izvrsne kovnice, dat će ti se savjet potpunoga spasa."

"Evo", rekoh, "vidi se torba puna novca.

Cijelu, dakako, poklanjam tebi, sveta Venero.

Ako daš savjet, kako bih bio dovoljno vedar, tvoj ću rod dovijeka štovati."

Po završetku tih uspješnih pregovora Venera traži od drugih stanovnika hrama da ih ostave nasamo, radi pikanterija koje slijede:

Innuens bis omnibus iubet ire cito.

$[\ldots]$

Exuit se vestibus genitrix Amoris, carnes ut ostenderet nivei decoris. sternens eam lectulo fere decem horis mitigavi rabiem febrici doloris. 
Dajući znak, svima ovima naredi da brzo odu. $[\ldots]$

Svukla je sa sebe odjeću roditeljica Amora, tijelo da pokaže snježnobijele ljepote.

Polegavši je na postelju, oko deset sati ublažavao sam bijes grozničave boli.

Zatim na red dolazi Jupiterova vrtna kupelj koja lirski subjekt dodatno čisti od prijašnjih slabosti te potom obilna gozba. Konačno:

Tribus, reor, mensibus secum sum moratus, plenum ferens loculum fui vir ornatus; recedens a Venere sum nunc allevatus nummis atque vestibus; sum sic pauperatus.

Terreat vos, iuvenes, istud quod auditis! dum sagittam Veneris penes vos sentitis, 98 mei este memores! Vos, quocumque itis, liberi poteritis esse, si velitis.

Tri sam se mjeseca, mislim, s njom zadržao, bio sam lijepo odjeven muškarac koji je nosio punu torbu; udaljivši se od Venere, sada sam olakšan od novaca i odjeće; tako sam osiromašen.

Neka vas plaši, mladići, to što čujete! Dok strijelu Venere kod sebe budete osjećali, mene se sjetite! Vi, kamo god budete išli, slobodni ćete moći biti, budete li htjeli.

(CB 76, st. 1-4, 7-8; 20-26; 33-52; 61, 65-68; 81-88)

Letimičnim čitanjem lako bi se mogao steći dojam o alegorijskoj naravi te poeme, interpretirajući ju kao ekstatičnu epizodu božanske audijencije, što potkrepljuje ambijent hrama, akustični podražaji u kojima lirski subjekt prepoznaje pjev sirena te čast koju on iskazuje Veneri pozdravljajući ju klečeći i uplašen njezinom prilikom te moleći spas od ljubavne boli. No, vinski delirij istaknut već na kraju prvoga stiha daje mogućnost alternativnog tumačenja, koje jasnije izlazi na vidjelo u drugoj polovici poeme, odnosno od dvanaeste 
strofe, kada Venera uvodi motiv novca (denarios) u zamjenu za "spasenje", čija je narav kasnije više nego jasno prikazana. Od tog trenutka počinje se raspadati alegorijska fasada, odnosno narativ se od alegorijskog božanskog susreta razgrađuje u metaforu koja iza imena Venere skriva prostitutku, što je paralelno odraženo u degradaciji nekoć bogatog i lijepo odjevenog lirskog subjekta u stanje bez novaca i odjeće, ali barem bez ljubavne boli. Završno siromaštvo tako otkriva dozu cinizma i (auto)ironije u antičkim motivima prethodno navedenima u poemi (posebno je zanimljiv Paris, opet kao simbol požude, koju je, doduše, lirski subjekt skupo platio) te služi kao opomena drugima, ističući mogućnosti, ali i opasnosti koje utjeha u "Veneri" donosi.

\section{CARMINA POTORIA}

Naravno, premda Venera dominira njima, carmina amatoria ne iscrpljuju se u njoj (niti su to sve pjesme u kojima obitava), pa tako ni u drugim spomenutim mitološkim motivima. Osim na nju može se naići na Cereru i Prozerpinu (CB 57), Tereja i Filomelu (CB 58, 71), ${ }^{7}$ stookog Arga (CB 70), Vulkana (CB 70, 152), Neptuna (CB 162), Herkula i njegove dogodovštine (CB 63, 64) te na još mnogo drugih. $U$ zbirci su svoje mjesto našli i pjesnički prijenosi starijih priča koji tematiziraju tragičnu ljubav Didone i Eneje (od CB 98 do 100), uvelike se oslanjajući na četvrto pjevanje Vergilijeve Eneide. Na njih se nastavljaju poema CB 101 o paležu Troje, od čijih četrdeset i pet strofa petina pripada Hekubinoj lamentaciji Junoni, te CB 102 koja u dvadeset i sedam strofa sažima Ilijadu i Eneidu, od otmice Helene do Enejine pobjede nad Turnom. No, dok se Venerina dominacija zbirkom temelji na brojnosti ljubavnih pjesama, u cjelini koja slijedi, carmina potoria, ona pada u sjenu, a vlast pripada Bakhu, ${ }^{8}$ bogu vina, koje golijardi skupa s njim slave i štuju:

${ }^{7}$ Za tragičnu priču o Tereju i Filomeli vidi: Ovidije, Metamorfoze VI.424-674.

Filomela (kasnije i Filomena) pretvorena je na koncu mita u slavuja (lat. philomena). Njegovo mjesto u poeziji zapadnoga kruga, pa i u Buranskim pjesmama, obradio je Vinko Grubišić, uz prepjeve triju pjesama iz zbornika. Vidi: Grubišić 2012: 9-28, 134-143.

${ }^{8}$ Bilo bi nepravedno propustiti barem spomenuti Decija, boga kocke i sličnih igara na sreću, kojemu pripada drugo mjesto i koji se javlja u pet pjesama zbornika (CB 195, 203, 219, 222 te 215 - posljednja je satirično kockarsko misno slavlje), s obzirom na to da je kockanje jedan od bitnih elemenata golijardske poezije, posebno vezan uz golijardima drago vino i krčmu. No, Decija ne obuhvaća tema ovog rada jer ne pripada nijednom antičkom panteonu, već je riječ o "tvorevini srednjovjekovnih pjesnika" (Grubišić 2010: 449). 
Bacche, bene venies gratus et optatus, per quem noster animus fit letificatus. [...]

Bacchus sepe visitans mulierum genus facit eas subditas tibi, o tu Venus. [...]

Bacchus venas penetrans calido liquore facit eas igneas Veneris ardore.

[...]

Bacchus numen faciens hominem iocundum, reddit eum pariter doctum et facundum. [...]

Bacche, deus inclite, omnes bic astantes leti sumus munera tua prelibantes. [...]

Omnes tibi canimus maxima preconia, te laudantes merito tempora per omnia.

Bakho, dobro došao drag i željen, po komu naša duša postaje razveseljena. [...]

Bakho koji često posjećuje rod ženâ čini ih podložnima tebi, o, ti Venero. [...]

Bakho koji u vene prodire strasnom tekućinom čini ih uspaljenima Venerinom strašću.

[...]

Bakho je božanstvo koje čini čovjeka radosnim, čini ga isto tako učenim i rječitim.

[...] 
Bakho, slavni bože, svi mi koji smo ovdje veseli smo tvoje darove kušajući.

$[\ldots]$

Svi tebi pjevamo najveće pohvale, tebe hvaleći po zasluzi za sva vremena.

(CB 200, 1-2, 9-10, 13-14, 29-30, 33-34, 37-38)

Premda je kršćanska alegoreza Bakha protumačila kao preteču Krista ili pretkršćanski ekvivalent Noi, Bakhova poveznica s vinom i pratećim posljedicama neizbježno ga je povezivala sa simboličkom, ali i praktičnom reprezentacijom tjelesnih i hedonističkih užitaka, posebice putenih (Brumble 1998: 49-51). Uz vrline navedene u gornjim stihovima Bakho se, kako Ovidije reče, ne slaže loše s Venerinim dječakom ("cum Veneris puero non male, Bacche, facis" - Ovidije, Ars amatoria III. 762), štoviše, ide ruku pod ruku s njim i njegovim poslovima te sudjeluje u poticanju ljubavi:

$\begin{array}{ll}\text { Bacchus ad amorem } & \text { Bakho na ljubav } \\ \text { instigat iuniorem, } & \text { potiče vrlo mladog, } \\ \text { mente rigidiorem } & \text { duhom vrlo krutog, } \\ \text { et hoc propere. } & \text { i to brzo. }\end{array}$

(CB 205, st. 29-32)

Jasno je, dakle, da je Ovidije i u slučaju Bakha izvor inspiracije. Stoga su ovi stihovi:

Bacchus lenis leniens curas et dolores, confert iocum, gaudia, risus et amores.

Bakho blagi, koji ublažuje brige i boli, donosi šalu, radosti, osmijehe i ljubavi.

(CB 200, st. 17-18)

usporedivi s:

vina parant animos faciuntque caloribus aptos:

cura fugit multo diluiturque mero.

tunc veniunt risus, tum pauper cornua sumit, tum dolor et curae rugaque frontis abit. 
Vina pripremaju duše i čine ih spremnima za strasti: briga bježi i slabi od obilnog čistog vina. Tada dolaze osmijesi, tada siromah rogove poprima, tada bol i brige i bora s čela odlaze.

(Ovidije Ars amatoria I.237-240)

Osim toga Bakho je od pomoći i kada ljubav ne ide po planu:

Cura Bacchus et sopore corda pio solvit more. sumpto Baccho meliore dulcis sapor est in ore; vini constat ex sapore letitia, recalescit in amore mens saucia.

(CB 202, st. 57-64)
Bakho od brige i tromosti srca blaženim oslobađa običajem. Kad se vrlo dobar Bakho uzme, sladak je okus u ustima; na okusu vina temelji se radost, grije se u ljubavi ranjena duša.

Druge mu božanske moći opisuju sljedeći stihovi, uz aluziju na epizodu o tvrdoglavom tebanskom kralju Penteju (preziratelju bogova, kako kaže Ovidije) koji je osporio Bakhu božanski status te dao utamničiti izvjesnog Aketa, njegova poklonika. No, budući da se u Aketovu obličju zapravo krio sam Bakho, cijela je stvar završila čudotvornim oslobođenjem boga i tragičnom smrću kralja (Ovidije, Metamorfoze III.510-733):

Tu das, Bacche, loqui, tu comprimis ora loquacis,

Ditas, deditas, tristia leta facis.

Concilias hostes, tu rumpis federa pacis,

Et qui nulla sciunt, omnia scire facis.

Multis clausa seris tibi panditur arca tenacis;

Tu das, ut detur, nil dare posse facis.

Das ceco visum, das claudo crura salacis:

Crederis esse deus, bec quia cuncta facis.

Ti daješ, Bakho, govoriti, ti obuzdavaš usta brbljavca,

Bogatiš, siromašiš, žalosne činiš veselima.

Izmiruješ neprijatelje, ti slamaš saveze mira,

I činiš da oni koji ne znaju ništa znaju sve.

Mnogim zasunima zatvorena tamnica tvrdoglavca tebi se otvara; 
Ti daješ da se daje, činiš da se ništa ne može dati.

Daješ slijepcu vid, daješ hromom noge pohotljivca:

Vjeruje se da si bog jer to sve činiš.

(CB 201, st. 1-8)

I slavni Arhipoeta ovisio je o Bakhovoj pomoći, kako sam kaže:

Tales versus facio, quale vinum bibo, nichil possum facere nisi sumpto cibo; nichil valent penitus, que ieiunus scribo, Nasonem post calices carmine preibo.

Michi numquam spiritus poetrie datur, nisi prius fuerit venter bene satur; dum in arce cerebri Bacchus dominatur, in me Phebus irruit et miranda fatur.

Takve stihove radim kakvo vino pijem, ništa ne mogu činiti ako ne uzmem hranu;

baš ništa ne vrijedi ono što natašte pišem, Nazona ću nakon kaležâ pjesmom nadmašiti.

Meni nikada duh poezije nije dan ako nije prije trbuh dobro nahranjen; dok u utvrdi mozga Bakho vlada, na mene Feb navaljuje i kazuje zadivljujuće stvari.

(CB 191, st. 69-76)

Bez vina (Bakha) nema poetskog nadahnuća (Feba), dakle tek s glavom punom vina Arhipoeta može nadmašiti spomenuti autoritet, odnosno Ovidija. Na njega se poziva vino u prepirci s vodom, nastaloj uslijed neželjenog miješanja dviju tekućina, kako bi se laskavo tituliralo:

Ego deus, et testatur istud Naso; per me datur cunctis sapientia.
Ja sam bog, i svjedoči to Nazon; po meni je dana svima mudrost.

Nakon daljnjeg hvalisanja i razmjene uvreda debata završava s vodom u suzama i bez riječi, uz molitveni zaključak moderatora: 
Ego Petrus disputator

buius cause terminator

omni dico populo:

quod hec miscens execretur

et a Christo separetur

in eterno seculo. Amen.
Ja, Petar raspravljač, ovog spora omedivač, cijelom puku kažem: neka je proklet koji ove miješa i Krist neka ih odvoji za vijeke vjekova. Amen.

(CB 193, st. 85-87, 100-102, 169-174)

Kako carmina potoria demonstriraju, ovdje nema traga kršćanskoj alegorezi te Bakho ima vrlo jednostavnu funkciju u tim slavljenjima hedonističkog svjetonazora - lako je razumljiva metafora za vino. No, budući da tu figuru ne zahtijevaju ni rima ni metrika (dapače, Bacchus i vinum su dvosložnice i obje pripadaju drugoj deklinaciii), Bakho prije svega služi kao dodatni subverzivni element u za svoje vrijeme ionako kontroverznim i moralno dvojbenim pjesmama, posvećenim krčmarskim i kockarskim aktivnostima.

Protiv miješanja vina i vode prosvjeduju još dvije pjesme koje se služe Bakhovim nadimcima:

In cratere meo Thetis est sociata Lyeo;

[...] sit deus absque dea.

Res tam diverse, licet utraque sit bona per se, Si sibi perverse coeant, perdunt pariter se.

U mojoj posudi Tetida je združena Lijeju; [...] neka je bog bez božice.

Stvari tako različite, makar obje bile dobre po sebi, ako bi se sastajale sebi protivne, uništavaju se zajedno.

(CB 194, st. 1, 4-6)

Lijej je tek jedan od brojnih Bakhovih pridjevaka, a znači osloboditelj (od briga). Vodu simbolizira Ahilova majka Tetida, jedna od nerejida, odnosno morskih nimfi. Pretpostavljam da se u drugoj pjesmi upravo ona krije u neimenovanoj božici sukobljenoj s Liberom (starijim bogom plodnosti, čije je ime naknadno poslužilo kao nadimak za Bakha):

Dea deo ne iungatur! deam deus aspernatur;
Božica neka se s bogom ne združi! Božicu bog prezire; 
nam qui Liber appellatur, libertate gloriatur.

[...]

numquam Bacchus adaquari se voluit, neque libens baptizari sustinuit. naime, onaj koji se zove Liber slobodom se ponosi.

[...]

nikada Bakho pribaviti vodu sebi nije želio, niti je rado biti kršten trpio.

(CB 202, st. 33-36, 45-48)

Svakako, Bakho nije usamljen među carmina potoria, no drugi mitološki motivi morat će se strpjeti jer bi njihovo uključivanje zahtijevalo mnogo opsežniji rad. Iza spomenute cjeline slijede ludi, dva igrokaza koja se bave okolnostima Isusova rođenja i bijegom od Heroda u Egipat, od kojih drugi sadrži motive antičke mitologije, ali budući da je tematika očito kršćanske provenijencije, ne bih se zadržavao na njima. Spomenuo bih još samo supplementum, u kojem rimsko-grčka mitologija gotovo iščezava, ${ }^{9}$ a judeo-kršćanski motivi opet dolaze na svoje, s obzirom na to da se uglavnom radi o religioznoj poeziji, pjesmama memento mori te kršćanskim exempla, od kojih su četiri posvećena mučeništvu sv. Katarine Aleksandrijske pod carem Maksencijem. ${ }^{10}$

\section{ZAKLJUČNI KOMENTARI}

Očito je obilje antičkih mitoloških ličnosti koje prožimaju zbornik Carmina Burana. Premda je tek manji dio njih ugledao svjetlo dana u ovome radu, dovoljno ih je da vrlo plastično demonstriraju da antička tradicija nije trebala čekati humaniste i da ju srednji vijek nije zaboravio, već joj je književna produkcija tog vremena s velikim zadovoljstvom pružala gostoprimstvo, ugledajući se na nju te crpeći znanje i inspiraciju iz njezina bogatog vrela. Sadržajna i formalna raznolikost zbirke Carmina Burana tek je jedno, ali značajno svjedočanstvo aktivnog intertekstnog odnosa između antike i srednjovjekovlja, stoga je paradoksalno da zbirka kao takva gdjekad prođe

\footnotetext{
${ }^{9}$ Istaknuo bih tek CB $8^{*} \mathrm{u}$ čijim se stihovima kriju Paris i Helena, zato što je ta pjesma identična pjesmi CB 111 te zato što se prepjev te pjesme nalazi u: Grubišić 2010: 354-357.

${ }^{10}$ To su CB $12^{*}, 21^{*}, 22^{*}$ te $19^{*}$ koju je prepjevao Šešelj. Vidi: Šešelj 2000: 26-29.
} 
"ispod radara". Egzemplaran je leksikon H. Davida Brumblea kojim sam se ovdje služio, Classical Myths and Legends in the Middle Ages and the Renaissance, koji se bavi alegorijskim značenjima klasičnih mitoloških figura u srednjovjekovnoj i renesansnoj književnosti, ali koji pritom sustavno zaobilazi Buranske pjesme unatoč varijacijama u svrhama mitoloških motiva i odnosima uspostavljenim prema njima u zborniku. Izostavljanje Buranskib pjesama u Brumbleovu leksikonu čudi tim više što su mu one mogle ponuditi bogatstvo građe za analizu i oprimjerivanje više alegorijskih tipova koje navodi u uvodu (Brumble 1998: xx-xxi).

Moralistička alegorija posebice je izražena u zborniku; ta figura obuhvaća one mitološke likove koji utjelovljuju vrline, mane i druge duševne karakteristike, poput mudrosti, čednosti, žudnji, fizičkih i društvenih potreba i slično. Venera i Bakho najjednostavniji su i najučestaliji primjeri za tu vrstu, pa tako prva stoji najčešće umjesto požude i putenosti, a potonji redovito predstavlja enološka uživanja, u čemu golijardski svjetonazor ne vidi mane niti pokazuje moralne dvojbe. U sukobu Venere i Minerve (CB 56) stoga valja čitati sukob karnalnog i racionalnog; Parisov izbor božice ljubavi za najljepšu sveo ga je na požudne implikacije (CB 103, 143, 147) te najčešće 106 služi kao autoreferencijalna figura, zbog svojega odnosa s božicom koja mu je darovala Heleninu ljubav. Slično se desilo i Apolonu zahvaljujući epizodi s Dafnom, koja je pak postala simbol čednosti i neuzvraćene ljubavi (CB $56,109)$.

Jupiterove preljubničke avanture također su poslužile da ga se svede na požudu (CB 83), premda to nije jedina Gromovnikova svrha. Posebno je pritom zanimljiva treća pjesma zbornika, društveno angažirana u ogoljivanju grijeha koji su proželi suvremeni joj svijet, napose škrtosti, laži, pohlepe i ljudima imanentne požude. Sveobuhvatnost posljednjega grijeha izražena je vlašću koju ima i nad ljudskom i nad božanskom razinom. Upravo Jupiter predstavlja potonju, što je neobično jer se stječe dojam da su mu preljubi kakva novost, a ne otprije i nadaleko poznata stvar:

Ecce torpet probitas, virtus sepelitur; fit iam parca largitas parcitas lagitur; verum dicit falsitas, veritas mentitur. $[\ldots]$
Evo, utrnulo je poštenje, vrlina se pokapa; sada škrtom postaje darežljivost, škrtost izdašno dijeli; istinu kazuje laž, istina laže. 
Regnat avaritia, regnant et avari;

[...]

Cunctis est equaliter insita cupido;

perit fides turpiter, nullus fides fido, nec Iunoni Iupiter nec Enee Dido.
Vlada pohlepa i pohlepni vladaju; [...]

Svima je jednako urođena požuda; nestaje vjera sramotno, nitko nije vjeran vjernomu, ni Junoni Jupiter, ni Eneji Didona.

(CB 3, st. 1-6, 10-11, 28-33)

S druge strane, upravo je epizoda između Jupitera i Danaje, uz pomoć drugih mitoloških likova, poslužila za demonstraciju moći zlata, elokventnijeg od Tulija (Cicerona) i uvjerljivijeg od bilo kojeg njegova govora, u kontekstu kritike pape i Rimske kurije:

Pape ianitores

Cerbero surdiores.

in spe vana plores,

nam etiamsi fores

Orphëus, quem audiit

Pluto deus

Tartareus,

$[\ldots]$

Iupiter, dum orat

Danen, frustra laborat;

sed eam deflorat, auro dum se colorat:

auro nil potentius, nil gratius,

nec Tullius

facundius perorat.

sed hos urit acrius,

quos amplius honorat;

nichil iustius,

calidum Crassus dum vorat!

(CB 131a, st. 13-19, 37-48)
Papini vratari

od Kerbera su gluši.

U zaludnoj nadi bi plakao, pa makar bio i

Orfej, koga je slušao

Pluton, bog

tartarski,

[...]

Jupiter, dok moli

Danaju, uzalud se trudi;

ali ju oskvrnjuje,

zlatom kad se boji:

od zlata ništa nije moćnije,

ništa nije draže,

ni Tulije

rječitije ne govori.

Ali one uspaljuje jače

koje obilnije časti;

ništa nije pravednije

nego kad ga usijanog Kras proždire! 
Kad je riječ o antiklerikalnim stihovima u zbirci, naći će se nimalo laskave figure, poput Scile i Haribde koje slikovito dočaravaju gramzivost visokih klerikalnih krugova:

$\begin{array}{ll}\text { Ibi latrat Scylla rapax } & \text { Ondje laje Scila gramziva } \\ \text { et Charybdis auri capax } & \text { i Haribda zlato koja guta } \\ \text { potius quam navium; } & \text { radije nego brodovlje; } \\ \text { ibi cursus galearum } & \text { ondje prolaze galije } \\ \text { et conflictus piratarum, } & \text { i sukobljavaju se pirati, } \\ \text { id est cardinalium. } & \text { to jest kardinali. }\end{array}$

(CB 41, st. 19-24)

Nadalje, osim kršćanskih ima i pretkršćanskih exempla, a najbolje primjere nude pjesme o Fortuni koje upozoravaju na njezinu prevrtljivost podsjećajući na nesretne sudbine Hekube (CB 16) te Darija i Pompeja (CB 14). Carmina Burana poznaju i astrološku alegoriju, a budući da dosada nije bila citirana nijedna pjesma s tom figurom, ovdje ispravljam nepravdu:
Iove cum Mercurio Geminos tenente
et a Libra Venere Martem espellente
virgo nostra nascitur, Tauro tunc latente.
Kada Jupiter s Merkurom Blizance drži
i od Vage kada Venera tjera Mars,
djeva naša rodi se, tad kada se Bik skriva.
(CB 88a, st. 1-3)

Slična je fizička (prirodna ili kozmička) alegorija, u kojoj se "bogovi interpretiraju kao reprezentacija elemenata prirodnog svijeta" (Brumble 1998: xx), poput Apolona/Feba u značenju Sunca:

$\begin{array}{ll}\text { Axe Phebus aureo } & \text { Kolima Feb zlatnim } \\ \text { celsiora lustrat } & \text { visine obilazi } \\ \text { et nitore roseo } & \text { i sjaja ružičastog } \\ \text { radios illustrat. } & \text { zrake odašilje. }\end{array}$

(CB 71, st. 1-4)

Ili različitih vjetrova, u ovom slučaju sjeverca i zapadnog vjetra, čija smjena najavljuje proljeće: 
Iam horrifer Aquilo suavi cedit Zephiro

(CB 132, st. 77-78)
Sada strašni Akvilon ugodnom ustupa mjesto Zefiru.

No, antičkih i mitoloških motiva ostalo je još napretek, i eksplicitnih i implicitnih, ali negdje se ipak treba zaustaviti. Ukratko, Carmina Burana svakako su plodan i zahvalan artefakt za različite analitičke pristupe, kojemu hrvatska književna historiografija (pa ni prevoditeljstvo), iako ga nije u potpunosti zanemarila kao Brumbleov leksikon, nije posvećivala mnogo pozornosti, kao ni problematici golijarda i njihove poetike. Daleko je ovo od njezina rješenja, dapače, ali je zato barem kratak uvid u (više ili manje) prihvaćene konvencije golijardske poezije temeljen na praktičnoj demonstraciji njezinih ostvarenja, s naglaskom na mitološkim motivima antičke rimske i grčke tradicije koji skupa s vještim služenjem latinskim jezikom odaju učenost njezinih autora. Erudicija tih nesretnih golijarda počiva upravo na poznavanju antičke baštine, ponajprije Ovidijevih djela koja su im poslužila kao vrelo inspiracije za stvaranje bogate subverzivne poezije, u kontekstu jačanja moći papinstva i Crkve te razvijajuće intelektualne klime. Premda rimski bogovi sami po sebi nužno ne impliciraju subverzivnost, golijardsko ih je pjesništvo iskoristilo upravo na subverzivan način, prije svega za antiklerikalnu kritiku te reprezentaciju i slavljenje krčmarskih, kockarskih i putenih aktivnosti. Te su aktivnosti, blago rečeno, bile daleko od uzoritog života za koji se nastojalo pridobiti klerike, kojima su golijardi pripadali ili su im barem bili bliski kroz različite statuse i položaje vezane uz obrazovne i crkvene institucije.

Tablica 1. Učestalost antičkih motiva u zbirci Carmina Burana

\begin{tabular}{|c|c|c|c|c|c|c|}
\hline & 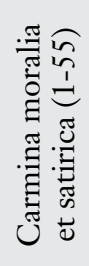 & 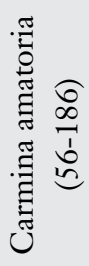 & 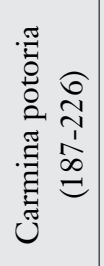 & 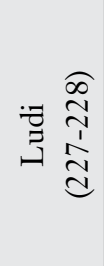 & 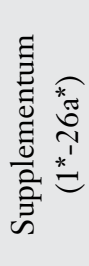 & $\begin{array}{l}0 \\
Z \\
5 \\
5 \\
5 \\
5\end{array}$ \\
\hline Akvilo/Borej & & 7 & 1 & & 1 & 9 \\
\hline Amor* & & 31 & 1 & & & 32 \\
\hline Bakho/Lijej/Liber & & 2 & 12 & & & 14 \\
\hline
\end{tabular}


T. Čanković, Antički i mitološki motivi u zbirci Carmina burana (73-113)

"Umjetnost riječi" LXIV (2020) • 1-2 • Zagreb • siječanj - lipanj

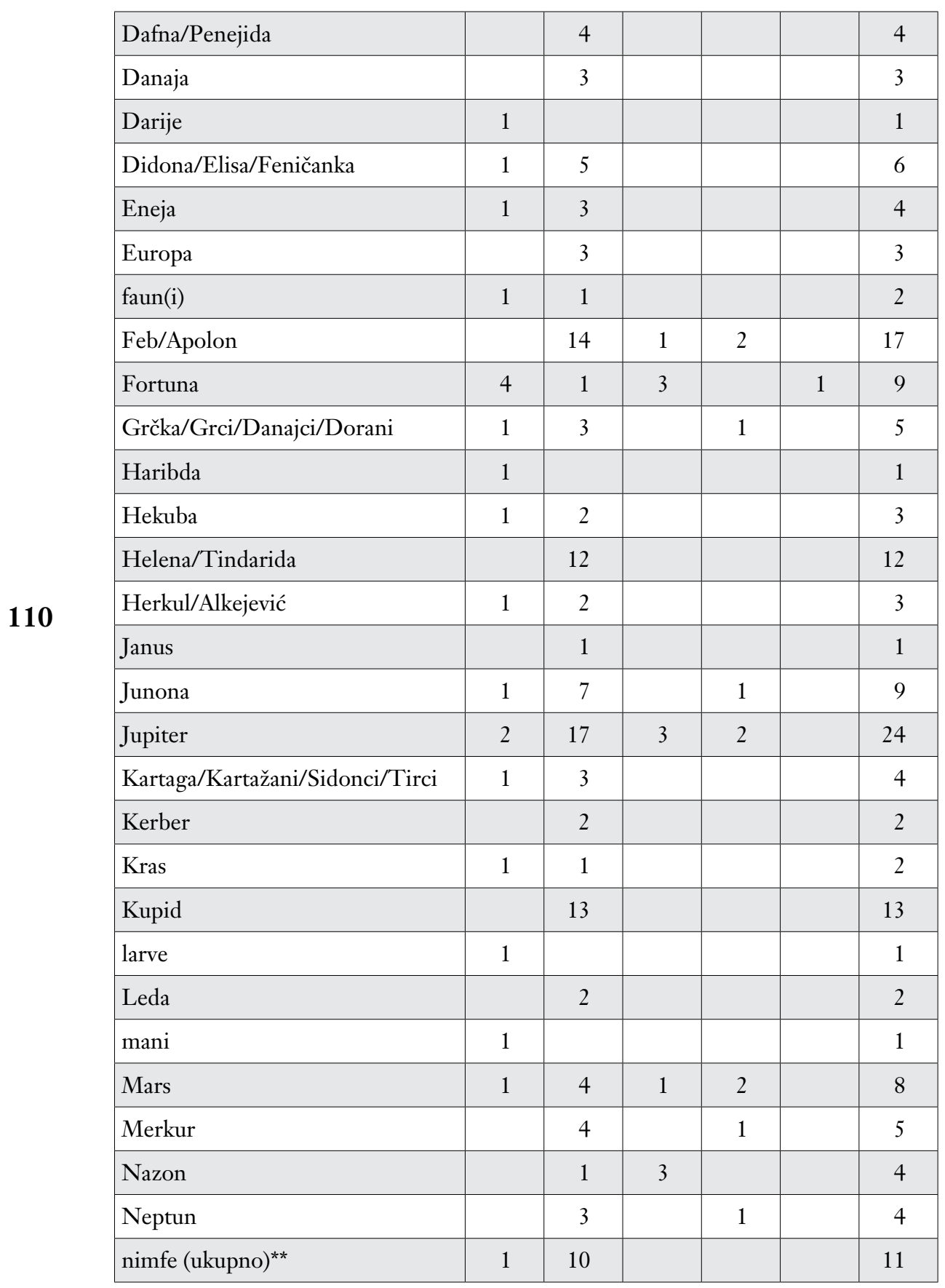


T. Čanković, Antički i mitološki motivi u zbirci Carmina burana (73-113)

"Umjetnost riječi" LXIV (2020) • 1-2 • Zagreb • siječanj - lipanj

\begin{tabular}{|c|c|c|c|c|c|c|}
\hline Orfej & & 2 & 1 & & & 3 \\
\hline Palada/Minerva & & 6 & & 1 & & 7 \\
\hline Paris & & 12 & 1 & & & 13 \\
\hline penati & 1 & & & & & 1 \\
\hline Pentej & & & 1 & & & 1 \\
\hline Pluton & 1 & 4 & 1 & 1 & & 7 \\
\hline Pompej & 1 & & & & & 1 \\
\hline $\operatorname{Rim}^{* * *}$ & 1 & & & & & 1 \\
\hline satiri & 1 & 3 & & & & 4 \\
\hline Scila & 1 & 3 & & & & 4 \\
\hline sirene & 2 & 1 & & & & 3 \\
\hline Tetida & 1 & 1 & 2 & & & 4 \\
\hline Troja/Trojanci/Frigijci & 1 & 5 & 1 & & & 7 \\
\hline Tulije (Ciceron) & 2 & 1 & & & & 3 \\
\hline $\begin{array}{l}\text { Venera/Kiteranka/Cipranka/ } \\
\text { Diona }^{* * * *}\end{array}$ & 2 & 67 & 5 & 2 & 1 & 77 \\
\hline Zefir (Favonije) & & 7 & & & & 7 \\
\hline
\end{tabular}

Napomena: brojevi u tablici označuju u koliko se pjesama (i koliko u kojim cjelinama) javljaju pojedini motivi, neovisno o tome koliko puta oni dolaze u pojedinoj pjesmi. Također, ova tablica nije ni približno iscrpna jer ovih četrdeset osam motiva čine tek oko četvrtine ukupno različitih antičkih motiva (više od dvjesto) prisutnih u zbirci ili, točnije, među pjesmama pisanim na latinskom jeziku. Praktičnijim mi se učinilo tablicu ovako "suziti" na one motive koji se spominju u citiranim stihovima i pratećim komentarima, uz dodatak Marsa i Merkura, relativno čestih likova (prvi se nalazi u osam, a drugi u pet pjesama). Za sve ostale motive naći će se manje od pet prebivališta: Epikur, Katon i Protej dolaze u četirima pjesmama; Hidra, Ahil, parke, Cerera, Saturn, Vulkan, muze i Didonina sestra Ana samo u trima; još dvadesetak ih se nalazi u dvjema pjesmama, a čak oko sto dvadeset u samo jednoj.

* O učestalosti ovoga božanstva svakako se može diskutirati jer neće svi interpretatori jednako zaključiti kada je riječ samo o ljubavi (amor), a kada o samom njezinu upravitelju (Amor).

** Nimfe sam ovdje grupirao pod navedenim hiperonimom, premda se one spominju i partikularno, gdjekad i unutar iste pjesme: drijade čak četiri puta, nimfe kao takve tri puta, a pijeride, hesperide, oreade, napeje, najade, plejade i misteriozne adrijade po jednom. 
*** Prolista li tkogod zbirku, lako će primijetiti da se Rim ne spominje samo jednom, kako je u tablici zabilježeno. Međutim, budući da sve druge pjesme sadrže Rim kao središte pape i kršćanstva, a ne kao antičku veličinu, nisam držao potrebnim uključiti ih u tablicu, u skladu sa svjesnim ignoriranjem judeo-kršćanskih motiva u ovome radu.

**** Kako se vidi iz tablice, Venera daleko nadvisuje ostale motive u zbirci. Napomenuo bih samo da sam ovdje uvrstio i tri pjesme u kojima se samostalno javlja ime Dione jer je gotovo sigurno riječ o redovitoj alternativi za Veneru (samo za CB 73 mogu sa sigurnošću reći da se Diona odnosi na Venerinu majku, no u toj se pjesmi obje i pojavljuju). Diona se inače spominje u dvanaest pjesama.

\section{LITERATURA}

Augustin, Aurelije. 1995a. O državi Božjoj = De civitate Dei, svezak prvi (knjiga I-X), 2. izd. Preveo Tomislav Ladan. Uvod napisali Agostino Trapè i Robert Russell, Sergio Cotta. Zagreb: Kršćanska sadašnjost.

Augustin, Aurelije. 1995b. O državi Božjoj = De civitate Dei, svezak drugi (knjiga XI-XVIII). Preveo Tomislav Ladan. Uvod napisali Agostino Trapè i Domenico Gentili. Zagreb: Kršćanska sadašnjost.

Bibliotheca Augustana. Amores.

112 http://www.hs-augsburg.de/ harsch/Chronologia/Lsante01/Ovidius/ovi_amo0.html (zadnji pristup 9. 5. 2019)

Bibliotheca Augustana. Ars amatoria.

http://www.hs-augsburg.de/ harsch/Chronologia/Lsante01/Ovidius/ovi_ars0.html (zadnji pristup 9. 5. 2019)

Bibliotheca Augustana. Carmina Burana.

http://www.hs-augsburg.de/ harsch/Chronologia/Lspost13/CarminaBurana/bur_car0. html (zadnji pristup 16. 4. 2020)

Brumble, H. David. 1998. Classical Myths and Legends in the Middle Ages and the Renaissance: A Dictionary of Allegorical Meanings. Westport, CT: Greenwood Press.

Carpenter, Clare. 2001. "Medievalism and paganism: interpretations of the Carmina Burana". Ph.D. diss, University of York.

Curtius, Ernst Robert. 1998. Europska književnost i latinsko srednjovjekovlje, 2. izd. Preveo Stjepan Markuš. Zagreb: Naprijed.

Dimmick, Jeremy. 2003. "Ovid in the Middle Ages: authority and poetry". U: The Cambridge Companion to Ovid. Ur. Philip Hardie. Cambridge: Cambridge University Press: 264-287.

Grubišić, Vinko. 2010. Latinska poezija srednjega vijeka. Zagreb: Alfa.

Grubišić, Vinko. 2012. Krilati pjev: Filomela i slavuj u poeziji zapadnog kruga. Zagreb: Topical.

Leyser, Henrietta. 2010. "Clerical purity and the re-ordered world". U: The Cambridge History of Christianity, Volume IV: Christianity in Western Europe c. 1100-c. 1500. Ur. Miri Rubin i Walter Simons. Cambridge: Cambridge University Press: 11-21. Mrkonjić, Zvonimir i Mirko Tomasović (ur.). 2012. Trubaduri. Preveli Morana Čale, Zeljka Čorak et al. Zagreb: ArTresor naklada. 
Ovidije Nazon, Publije. 2008. Metamorfoze. Preveo Tomo Maretić. Zagreb: Europapress holding.

Raby, Frederic James Edward. 1997. A History of Secular Latin Poetry in the Middle Ages, Volume II. Oxford: Oxford University Press.

Šešelj, Zlatko (ur.). 2000. Carmina Burana: izbor. Preveo Zlatko Šešelj. Zagreb: Matica hrvatska.

Waddell, Helen. 1961. The Wandering Scholars: The Life and Art of the Lyric Poets of the Latin Middle Ages, 6. izd. Garden City, NY: Doubleday \& Company.

\section{Abstract}

\section{ANTIQUE AND MYTHOLOGICAL MOTIFS IN CARMINA BURANA}

This paper discusses the function, purpose, place and formal characteristics of the Greek and Roman mythological motifs in the poems that are part of Carmina Burana, a medieval collection of poetry dating from the first half of the 13 th century. Different relations established between the aforementioned motifs and lyrical subjects are also examined, as well as how these motifs fit into the context of the individual poem and the entirety of Carmina Burana. The paper focuses exclusively on the motifs which belong to the ancient Greek and Roman traditions, and not on those of the Judeo-Christian provenance, although the latter are numerous in their own right. Also, as Publius Ovidius Naso is often regarded as the main influence on the goliards, traces of his works and militaristic concepts of love visible in the poems of Carmina Burana are also highlighted and examined. The focus of this paper is on those poems which belong to the basic thematic elements usually attributed to the goliards, including tavern, wine, gambling, physical love and satirical and anticlerical overtones.

Keywords: goliards, Carmina Burana, medieval Latin poetry, mythological motifs, Ovid 